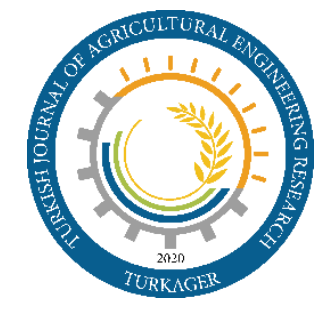

Turkish Journal of Agricultural Engineering Research

https://dergipark.org.tr/en/pub/turkager

https://doi.org/10.46592/turkager.2020.v01i02.010

Turk J Agr Eng Res

(TURKAGER)

e-ISSN: $2717-8420$

2020, 1(2): 339-353

Research Article (Araştırma Makalesi)

\title{
Sultansuyu Tarım İşletmesi Süt Sığırcılığı Faaliyetlerinde Girdi ve Maliyetlerin Belirlenmesi
}

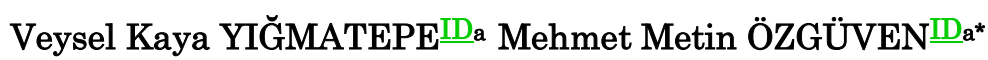 \\ aBiyosistemMühendisliğiBölümü, ZiraatFakültesi, TokatGaziosmanpaşaÜniversitesi, Tasliciftlik, Tokat, TÜRKIYE \\ (*): Corresponding author, metin.ozguven@gop.edu.tr; Tel: +90-356-2521616, Fax: +90-356-2521488
}

\section{ÖZET}

Bu çalışmada, asıl kuruluş amacı damızlık hayvan ve tohum üretimi olarak 2 kısım altında toplanabilecek TíGEM'in Malatya ilinde bulunan Sultansuyu Tarım İşletmesi Müdürlüğü'nün hayvancılık şubesi süt sığırcılığı bölümünün girdi ve maliyetlerinin belirlenmesi amaçlanmıştır. 2011-2015 yılları arası gerçek üretim şartlarında süt sığırcılığg faaliyetine ilişkin muhasebe ve işletme kayıtları kullanılmıştır. 2011-2015 yılları arası ortalaması olarak çalışma sonuçları, işletmenin masraf unsurları arasında toplam maliyet \%59.6 ile yem masrafları, \%19.34 ile teknik eleman ve işçi masrafları, \%11.16 ile amortisman giderleri, \%6.14 ile diğer giderlerin ve ilaç giderlerinin \%3.76'yı oluşturduğu tespit edilmiştir. Gelir kaynaklarının ise; \%41.76’lk kısmının süt gelirleri, \%29.52 ile damızlık ve reforme gelirleri, \%20.02 ile çağ farkı gelirleri, \%8.56 ile gübre gelirleri ve 0.1 ile sığır derisinden oluştuğu belirlenmiştir.

\section{ARAŞTIRMA MAKALESI}

Alınış tarihi: 05.08.2020

Kabul tarihi: 05.09.2020

Anahtar Kelimeler:

$>$ Ekonomik analiz,

$>$ Süt sığırcılığı,

$>$ Süt maliyeti,

$>$ Tarım işletmeleri

Alıntı için: Yığmatepe V K, Özgüven M M, (2020). Sultansuyu Tarım İşletmesi Süt Sığırcılığı Faaliyetlerinde Girdi ve Maliyetlerin Belirlenmesi. Turkish Journal of Agricultural Engineering Research (TURKAGER), 1(2): 339-353. https://doi.org/10.46592/turkager.2020.v01i02.010 


\section{Determination of Inputs and Costs in Dairy Farms Activities of Sultansuyu Agriculture Enterprises}

\begin{abstract}
In this study, it was aimed to determine the inputs and costs of the milk cattle section of the animal husbandry branch of Sultansuyu Agricultural Directorate in Malatya province, which will be able to be gatheredunder 2 parts as the main establishment aim breeding and seed production. In the actual production conditions of the years 2011-2015, the accounting and operating records related to dairy cattle activity were used. According to results 2011-2015 averages; percentage of total cost of the enterprise's costelements was found to be $59.6 \%$ forfeed costs, $19.34 \%$ fortechnical staffandlabor costs, $11.16 \%$ foramortization expenses, other expenditures with $6.14 \%$ and drug costs with $3.76 \%$. Income sources were determined as $41.76 \%$ milk incomes, $29.52 \%$ breeding and reforming incomes, $20.02 \%$ ages difference incomes, $8.56 \%$ fertilizer incomes and 0.1 and cattle breeds.
\end{abstract}

\section{RESEARCH ARTICLE}

Received: 05.08.2020

Accepted: 05.092020

\section{Keywords:}

$>$ Economic analysis,

$>$ Dairy cattle,

$>$ Milk cost,

$>$ Agricultural enterprises

To cite: Yığmatepe V K, Özgüven M M, (2020). Determination of Inputs and Costs in Dairy Farms Activities of Sultansuyu Agriculture Enterprises. Turkish Journal of Agricultural Engineering Research (TURKAGER), 1(2): 339-353.

https://doi.org/10.46592/turkager.2020.v01i02.010

\section{GİRİ̧̧}

Hayvansal üretimde ilk istenen koşul et ve süt verimi yüksek irklarla yetiştiricilik yapılmasıdır. İkinci olarak hayvanların yeterli ve dengeli beslenerek hayvanların bireysel potansiyelinden en yüksek düzeyde yararlanılmasıdır. Üçüncü olarak ise hayvansal üretimde en büyük kayıpların yaşanmasına sebep olan hastalıklara karşı koruyucu sağlık önlemlerinin alınması ve hastalıkların erken teşhis edilerek gerekli müdahalenin anında yapılmasıyla sağlık giderlerinin en aza indirilmesidir (Özgüven, 2017). Hayvancılık sektörü; nüfusun beslenmesine katkısı yanında, değişik üretim kollarına hammadde sağlaması, istihdam, lojistik sektörün ve perakendeciliğin gelişmesine sağladığı değer artışları, kırsal kalkınmanın gerçekleştirilmesi, kalkınma finansmanının öz sermayeye dayandırılması gibi önemli ekonomik fonksiyonlar üstlenmiştir (Anonim, 2015a). Tarımsal üretimin sürdürülebilirliği açısından çok önemli olan hayvancılık faaliyeti, bitkisel üretimin yanında yapılmasıyla insan gıdası olarak tüketilemeyen mera bitkileri, diğer kaba yemler, tarımsal ürün ve gıda sanayi artıklarının değerlendirilmesi sağlanmakta ve tarım işletmelerinin ekonomik olarak faaliyetini yılın her döneminde gerçekleştirebilmesi sağlanmaktadır.

Yeterli ve dengeli beslenme bireylerin sağlığının korunması ve geliştirilmesinde önemli rol oynayan besinler dört gruba ayrılmıştır. Bu dört besin grubu; et ve et ürünleri, süt ve süt ürünleri, sebzeler ve meyveler ile ekmek ve tahıllardır. Süt ve süt ürünleri grubunda yoğurt, peynir ve süt tozu gibi sütten yapılan besinler yer almaktadır. Bu besinler protein, kalsiyum, fosfor, B2 vitamini ve B12 vitamini olmak üzere birçok besin öğesinin önemli kaynağıdır (Ünal ve Besler, 2008). Hayvansal besinlerdeki protein miktarları ette \%15-20, balıkta \%19-24, yumurtada \%12, sütte \%34, peynirde ise \%15-25'dir. Sağlık açısından kırmızı et, beyaz et, süt, yumurta gibi 
hayvansal ürünlerin düzenli olarak tüketilmesi gerekmektedir. Ancak, ülkemizde tüketilen günlük protein miktarının \%73'ü bitkisel kökenli gıda maddelerinden karşılanmaktadır (Anonim, 2013a). Yapılan araştırmalarda yetişkin bir insanın günlük 70 g protein tüketmesi gerektiği ve bunun \%40'ının hayvansal kökenli proteinlerden oluşması gerektiği belirtilmektedir. Bu da sadece et, süt, yumurta ve bal gibi hayvansal kaynaklı proteinlerden sağlanabilmektedir. Ancak hayvansal kaynaklı gıdaların bitkisel kaynaklı gıdalara oranla daha yüksek maliyet ve daha karmaşı bir üretim planının olması, hayvansal kaynaklı gıdaların fiyatlarının daha yüksek olmasına sebep olmaktadır. Bu sebepledir ki hayvansal ürünlerin tüketiminin arttırılması, hayvan varlığının arttırılması ve ulaşılabilir düzeye getirilmesiyle mümkün olabilmektedir (Anonim, 2015b).

Başta et, süt ve yumurta gibi gida maddeleri olmak üzere insanların önemli ihtiyaçlarını karşılayan hayvancılık, tarımın önemli alt sektörlerinden biridir. FAO verilerine göre 2013 yılında tarım sektörü dünya gayri safi hasılasının \%3,1'ini oluşturmakta, hayvancılık sektörü ise tarımsal gayri safi hasılasının \%38'ini oluşturmaktadır. $\mathrm{Bu}$ oran $\mathrm{AB}$ ülkelerinde $\% 55$, ABD'de $\% 49$ iken gelişmekte olan ülkelerde yaklaşık \%36 civarındadır (Anonim, 2015c). Gelişmiş ülkelerde ortalama sığır karkas ağırlığı 250 kg dolayında iken, ülkemizde 160-170 kg'dır. Sığır başına laktasyon süt verimi bu ülkelerde ortalama 5000-6000 kg olup, ülkemizde 1400-1500 kg'dır. Ülkemizde hayvansal üretimin geliştirilmesi amacıyla hayvan ıslahı, hayvan hastalık ve zararlılarıyla mücadele, mera kullanımının düzenlenmesi ve yem bitkileri üretiminin arttırılması ile yayım hizmetleri yaygınlaştırılmalıdır (Anonim, 2000).

Ülkemizdeki süt üretimine ilişkin toplam işletme sayısı diğer ülkelere kıyasla oldukça yüksektir. Ancak işletmelerin sahip oldukları hayvan sayılarına göre kapasiteleri gruplandırıldığında ülkemizde çok sayıda küçük ölçekli süt işletmesi olduğu görülmektedir. AB üye ülkelerinde çiftlik başına düşen süt ineği sayısı 32,2 iken, ülkemizde bu ortalama 4.5 baş civarındadır. Ülkemizde 1,3 milyon olan süt işletmesi sayısının \%80'i 1-10 baş arası hayvana sahipken, işletmelerin \%20'lik bir kısmı 10 ve daha fazla hayvana sahip çiftliklerden oluşmaktadır. İşletmelerin sahip oldukları hayvan sayılarına göre küçük olması; girdi maliyetlerinin yüksek olmasına, süt verimi yüksek sığır ırklarının temininde güçlüklere, süt ve süt ürünlerinin pazarlanması ve genel anlamda süt sığırcılığının etkinliği ve verimliliğini sağlayacak olan örgütlenmede güçlüklere neden olmaktadır (Anonim, 2013b).

Süt sığırı yetiştiriciliği uzun vadeli planlamayı gerektiren bir yatırım kararıdır. Dolayısıyla yatırım döneminden başlayarak yatırım maliyeti ile birlikte ortaya çıkacak bütün gelir ve giderlerin göz önünde bulundurulması gerekmektedir. Yatırım döneminde inşaat ve makine ekipman maliyetleri önemli yer tutmaktadır. Üretim döneminde ise, ylllık direkt ilk madde malzeme (yem) maliyetleri, direkt iş̧̧ilik, sigorta, suni tohumlama, veteriner ve ilaç, elektrik, su, yakıt, bakım ve amortisman maliyetleri gibi birçok maliyet unsuru söz konusu olmaktadır. Bu maliyetlere karşın temel gelir kalemi süttür. Süt satışından elde edilen gelirin yanı sıra kasaplık ve damızlık hayvan satışından elde edilen gelirler (reforme inek, dişi ve erkek buzağı satışı) yıllık teşvik gelirleri ve gübre satış gelirleri süt inekçiliği üretim işletmelerinin temel gelir kaynaklarını oluşturmaktadır (Hacıhasanoğlu, 2015).

Türkiye'de farklı illerdeki sığırcılık işletmelerinin yapısal durumlarını ve ırk tercihlerini belirlemeye yönelik olarak daha önceki yıllarda yapılmış çalışmalar bulunmaktadır. Bu tip çalışmaların daha yaygın şekilde ve belirli aralıklarla 
tekrarlanması, alandaki verilerin güncellenmesi, sektördeki mevcut durumun tespiti, zaman içerisindeki değişimlerin takip edilebilmesi ve sorunlara çözümler üretilebilmesi yanında geleceğe yönelik gerçekçi planlamaların yapılabilmesi için de önem arz etmektedir (Şeker ve ark., 2012).

Bu çalışma, Tarım İşletmeleri Genel Müdürlüğü’ne (TİGEM) bağlı olan Malatya ili Akçadağ ilçesinde yer alan Sultansuyu Tarım İşletmesi Müdürlüğü’nde 2011-2015 yılları arası süt sığırcılığı faaliyetinde girdi ve maliyetlerin belirlenmesi için maliyeti oluşturan masraf unsurları, yem giderleri, sağlık giderleri ve gelir kaynakları alt başlıklar halinde incelenmiş ve işletmenin verimlilik rantabilite ilişkisi değerlendirilmiştir.

\section{MATERYAL ve YÖNTEM}

Çalışmanın ana materyalini Malatya ili Akçadağ ilçesinde yer alan Tarım İşletmeleri Genel Müdürlüğü’ne (TİGEM) bağlı Sultansuyu Tarım İşletmesi'nin (Sultansuyu TİM) Yeniköy arazileri içerisinde yapılan hayvancılık faaliyetleri içerisinde yer alan 247 ana kadroluk Montofon (Brown Swiss) cinsi süt sığırcılığ̣ faaliyetine ilişkin muhasebe ve işletme kayıtları oluşturmaktadır.

İşletmede sığırcılık şubesinde 1 Adet 90 BG ve 1 Adet 55 BG olmak üzere 2 adet traktör, 1 adet $12 \mathrm{~m}^{2}$ ve 1 adet $15 \mathrm{~m}^{2}$ olmak üzere 2 adet yemleme vagonu, 1 adet siyırgı 1 adet 12'li süt sağım tesisi ile 2 adet 4'er tonluk süt soğutma tankı bulunmaktadır. İşletme 2017 yılı itibariyle 300 baş ana kadro ve toplam 650 baş sığır varlığı ile hayvancılık faaliyetini sürdürmektedir.

Süt sığırlarının bulunduğu tesiste gündüz ve akşam vardiyalarında ilk olarak sağım gerçekleştirilmektedir. Gruplar halinde kendilerine ait padoklarda bulunan inekler yine gruplar halinde sağım tesisine yönlendirilip 12'li süt sağım tesisinde sağımları gerçekleştirilmektedir. Gruplar halinde sağım tesisine yönlendirilen hayvanlar bulundukları padokları terk ettiği andan itibaren 55 BG'lik traktör sığırların sağım dönüşü temiz ve ferah bir ortama dönüş yapabilmesi için sağım bitene kadar 3 nokta askı sistemine bağlı bir sıyırgı ile temizliği gerçekleştirmektedir. Sağım sonrası yeme ve suya ihtiyaç duyan hayvanların bu ihtiyaçlarını anında gidermek için 1 adet 90 BG'lik traktör çekilir tip yemleme vagonu ile hayvan başına $4.5 \mathrm{~kg}$ kesif yem, $1 \mathrm{~kg}$ yonca, $1 \mathrm{~kg}$ hasıl fiğg, $1 \mathrm{~kg}$ çayır otu ve $10.5 \mathrm{~kg}$ silaj olacak şekilde ayarlanmış rasyonu sağım esnasında yemliklere dağıtmaktadır.

Süt sağım tesisinde sağımın yanı sıra hasta hayvan tanıma, sağılmayan hayvan bildirim sistemi, süt verimi düşen hayvan bildirim sistemi ve her bir hayvan için süt verimi ölçme sistemi bulunmaktadır. Sağım esnasında hayvanlardan elde edilen süt ilk olarak sağım tesisinde bulunan 60 l'lik küçük tanka aktarılmaktadır. Tank dolunca şamandıra yardımıyla pompa çalıştırılıp büyük soğutma tanklarına süt gönderilmektedir. Soğutma tanklarına aralıklarla gelen süt soğutma tanklarında $4^{\circ}$ C'ye kadar soğutulup sistem otomatik olarak durmaktadır. Sicaklık $4^{\circ} \mathrm{C}$ nin üstüne çıktığında, soğutma sistemi otomatik bir şekilde tekrar çalışıp sıcaklığın taşıma araçlarına nakline kadar $4^{\circ} \mathrm{C}^{\prime}$ de tutulması sağlanmaktadır. Bu şekilde sağım sisteminde sağım tamamlandıktan sonra, soğutma tanklarında ise nakil işleminden sonra sistemin temizleme mekanizması devreye girip önce soğuk suyla durulama yapılmakta ardından sıcak su dezenfektan ile birlikte bütün sistemi dolaşıp sistemin temizliği yapılmakta ve son olarak soğuk su ile tekrar durulama yapılmaktadır. Sağım 
sisteminde ek olarak fanlar yardımı ile borularda sıvı kalmayacak şekilde sistemin kurulaması sağlanmaktadır.

Tarım işletmeciliği alanında yapılan araştırmalarda, materyalin toplanması aşamasında uygulanabilecek çeşitli yöntemler bulunmaktadır. Bunlar; Muhasebe Kayıtlarından Yararlanma, Direkt Mülakat Yöntemi ve Posta Surveyi olarak sıralanmaktadır (Çiçek ve Erkan, 1996). Direkt mülakat yönteminin maliyet, zaman, olası yanlılık, kayıtlı veya yazılı bilgileri kullanamama, zaman ayırma güçlüğü, gizliliğin ortadan kalkması, soru standardının olmayışı ve bireylere ulaşma güçlüğü gibi dezavantajları bulunmaktadır (MEB, 2012). Posta surveyi yöntemiyle toplanacak anket verilerinin üreticilerin eğitim eksikliği, kayıtsız kalma, soruların yanlış anlaşılması ya da anket formlarının geri dönmemesi gibi olumsuz yönleri bulunmaktadır. Ayrıca cari tarımsal üretim istatistikleri il/ilçe Tarım Müdürlügü çalışanlarının kendi bölgelerindeki izlenimlerine dayandığından objektif metotlarla ölçülecek değerlerle aralarında farklar olabileceği düşünülmektedir (Güneş ve Arıkan, 1985).

Sultansuyu Tarım İşletmesinde 2011-2015 yılları arasında gerçek üretim şartlarında süt sığırcılığ faaliyetine ilişkin tutulan muhasebe ve işletme kayıtları kullanılarak yapılan ekonomik analiz ile süt sığırcılığı faaliyetinin karlılık durumu incelenmiştir. Süt sığırcılı̆̆ belirlenmesi amacı ile maliyeti oluşturan masraf unsurları, yem giderlerinin, sağlık giderlerinin, diğer giderlerin ve gelir kaynaklarının detaylı bir şekilde incelenmesi ve BBHB düşen miktarlarının hesaplanmasıyla oluşturulmuştur. Hesaplamalarda aşağıdaki formüller kullanılmıştır. Burada Büyükbaş Hayvan Birimi (BBHB) (Erkuş ve ark., 1995), Alet ve Ekipmanların amortisman gideri (EKA) (Aras, 1988) ve Makine Değerleri Toplamı (MDT) (Aras, 1988).

BBHB $=\frac{E K A}{\text { İșletmedeki Toplam Hayvan Sayısı }}$

$E K A=\frac{M D T * 20-M D T * 9,85}{100}$

$1 \mathrm{Kg}$ Süt Maliyeti $=\frac{Y \_l \text { İçindeki Dĭger Masraflar }- \text { Yan Gelirler }}{\text { Bir Yıllık Toplam Süt Üretim Miktarı }}$

Çalışmada 2011-2015 yılları esas alınmış olup işletmenin muhasebe kayıtları hayvancılık şubesinin tuttuğu kayıtlar esas alınarak veriler analiz edilmiştir. Elde edilen sonuçlar Sultansuyu tarım işletmesi süt sığırcılığı faaliyetinde girdi ve maliyetlerin belirlenmesinde kullanılmıştır.

\section{BULGULAR ve TARTIŞMA}

\section{Maliyeti Oluşturan Masraf Unsurları}

Maliyeti oluşturan masraf unsurları iş gücü gereksinimleri, yem giderleri sağlık giderleri ve diğer giderler başlıkları altında bir araya getirilmiştir. Sultansuyu tarım işletmesi müdürlüğü süt sığırcılığı ve damızlık Limousin yetiştiriciliği işlerini tek çatı altında yürüttüğünden giderler ve gelirlerde hayvancılık şubesi olarak tek çatı altında 
toplanmıştır. Süt sığırcılığı maliyetleri hesaplanırken Büyük Baş Hayvan Birimi (BBHB) göz önünde bulundurulmuştur. Aras (1988), BBHB hesaplamasında buzağılar için (0-6 aylık) 0.20, genç hayvanlar için (7 -12 aylık) 0.40, dana ve düveler için (12 - 24 aylık) 0.70, inekler için ( $24+$ aylık) 1.0, boğalar için 1.20 katsayılarının kullanılmasını bildirmiş olmasına rağmen, Sultansuyu Tarım İşletmesi Müdürlüğü tarafından uzun yıllar inek, dana-düve, buzağı ağırlıkları ve yem tüketimlerini göz önünde bulundurularak kendi BBHB katsayılarını oluşturmuş ve bu çalışmada da BBHB hesaplanırken bu katsayılar kullanılmıştır.Bu katsayılar, inek ve boğalar 1 birim, düve ve tosunlar 0,6 birim, danalar 0,45 birim, buzağılar 0,2 birimdir. 2015 Yılında işletmede bulunan hayvan ırkları ve hayvan hareketleri Çizelge 1 ve Çizelge 2'de verilmiştir.

Çizelge 1.Sultansuyu tarım işletmesi2015 yılı sığırcılık hareketleri (Esmer Irkı)

Table 1. Sultansuyu agricultural enterprise 2015 cattle movements (Brown $S_{w i s s}$ Race)

\begin{tabular}{|c|c|c|c|c|c|c|c|c|c|}
\hline & Boğa & İnek & $\begin{array}{l}\text { Genç } \\
\text { Boğa }\end{array}$ & Düve & $\begin{array}{c}\text { Erkek } \\
\text { Dana }\end{array}$ & Dişi Dana & $\begin{array}{c}\text { Erkek } \\
\text { Buzağ1 }\end{array}$ & $\begin{array}{c}\text { Dişi } \\
\text { Buzağı }\end{array}$ & Toplam \\
\hline Yılbaşı Mevcudu & 0 & 253 & 0 & 112 & 7 & 44 & 45 & 42 & 503 \\
\hline Satın Alınanlar & & & & & & & & & 0 \\
\hline Doğanlar & & & & & & & 113 & 94 & 207 \\
\hline Çağdan Gelenler & 1 & 50 & 15 & 83 & 74 & 92 & & & 315 \\
\hline Girişler Toplamı & 1 & 303 & 15 & 195 & 81 & 136 & 158 & 136 & 1025 \\
\hline $\begin{array}{l}\text { Reforme } \\
\text { Edilenler }\end{array}$ & 1 & 42 & 0 & 7 & 2 & 1 & 1 & 2 & 56 \\
\hline Diğer İşl. Giden & & & & & 18 & & 13 & & 31 \\
\hline Dam. Satılanlar & & & & 25 & & & & & 25 \\
\hline Kesilenler & 0 & 8 & 0 & 0 & 1 & 0 & 1 & 0 & 10 \\
\hline Ölenler & 0 & 3 & 0 & 0 & 0 & 1 & 11 & 1 & 16 \\
\hline Çağa Gidenler & & & 1 & 50 & 15 & 83 & 74 & 92 & 315 \\
\hline Çıkışlar Toplamı & 1 & 53 & 1 & 82 & 36 & 85 & 100 & 95 & 453 \\
\hline Yilsonu Mevcudu & 0 & 250 & 14 & 113 & 45 & 51 & 58 & 41 & 572 \\
\hline
\end{tabular}

Çizelge 2. Sultansuyu tarım işletmesi 2015 yılı sığırcılık hareketleri (Limousin Irkı) Table2. Sultansuyu agricultural enterprise 2015 cattle movements (Limousin Race)

\begin{tabular}{|c|c|c|c|c|c|c|c|c|c|}
\hline & Boğa & İnek & $\begin{array}{l}\text { Genç } \\
\text { Boğa }\end{array}$ & Düve & $\begin{array}{l}\text { Erkek } \\
\text { Dana } \\
\end{array}$ & $\begin{array}{c}\text { Dişi } \\
\text { Dana } \\
\end{array}$ & $\begin{array}{c}\text { Erkek } \\
\text { Buzağ } \\
\end{array}$ & $\begin{array}{c}\text { Dişi } \\
\text { Buzağı } \\
\end{array}$ & Toplam \\
\hline Yllbaşı Mevcudu & 0 & 64 & 0 & 40 & 7 & 3 & 9 & 11 & 134 \\
\hline Satın Alınanlar & & & & & & & & & 0 \\
\hline Doğanlar & & & & & & & 31 & 32 & 63 \\
\hline Çağdan Gelenler & 0 & 21 & 10 & 13 & 27 & 26 & & & 97 \\
\hline Girişler Toplamı & 0 & 85 & 10 & 53 & 34 & 29 & 40 & 43 & 294 \\
\hline Reforme Edilenler & 0 & 11 & 0 & 0 & 0 & 0 & 0 & 1 & 12 \\
\hline Diğer İşl. Giden & & & & & 6 & & & & 6 \\
\hline Dam. Satılanlar & & & & & & & & & 0 \\
\hline Kesilenler & 0 & 1 & 0 & 0 & 0 & 0 & 0 & 0 & 1 \\
\hline Ölenler & 0 & 1 & 0 & 1 & 0 & 0 & 1 & 2 & 5 \\
\hline Çağa Gidenler & & & 0 & 21 & 10 & 13 & 27 & 26 & 97 \\
\hline Çıkışlar Toplamı & 0 & 13 & 0 & 22 & 16 & 13 & 28 & 29 & 121 \\
\hline Yll Sonu Mevcudu & 0 & 72 & 10 & 31 & 18 & 16 & 12 & 14 & 173 \\
\hline
\end{tabular}


Çizelge 1 ve Çizelge 2'de yer alan verilere göre Sultansuyu Tarım İşletmesi Müdürlüğünde 2015 Yılındaki Montofon ırkı BBHB 389,2 Limousin ırkı BBHB 177,1 olmak üzere toplam BBHB 566,3 tür.

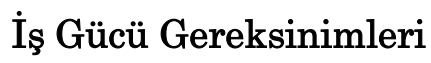

\section{Teknik Eleman ve İşçi Masrafları}

Sultansuyu Tarım İşletmesi 2011-2015 yılları arası çalışan sayıları Çizelge 3'de ve Çizelge 4'de ise 2011-2015 yılları arası personelin aldığı ücretlerin işletmeye yansıyan toplam yükü aşağıda gösterilmiştir.

Çizelge 3. Sultansuyu tarım işletmesi 2011-2015 yılları arası çalışan sayıları

Table 3. Sultansuyu agricultural enterprise number of employees between 2011 and 2015

\begin{tabular}{lccccc}
\hline & $\mathbf{2 0 1 1}$ & $\mathbf{2 0 1 2}$ & $\mathbf{2 0 1 3}$ & $\mathbf{2 0 1 4}$ & $\mathbf{2 0 1 5}$ \\
\hline Teknik Eleman Sayısı & 2 & 5 & 7 & 7 & 3 \\
Kadrolu İşçi Sayısı & 5 & 4 & 3 & 3 & 2 \\
Taşeron İşçi Sayısı & 12 & 15 & 15 & 13 & 13 \\
\hline
\end{tabular}

Çizelge 3'deki çalışan sayıları incelendiğinde, 2015 yılı baz alınırsa sığırcılık faaliyetlerini yürüten ve şube sorumluluğunu taşıyan 1 Ziraat Mühendisi (Zooteknist), hayvanların hastalık, tohumlama, rasyon ve verim takibinde bulunan 2 veteriner sağlık teknisyeni, işin ve iş̧̧ilerin iş bölümü ve takibinden, yemlemenin yapılmasından ve sağımın doğruluğunun kontrolünden sorumlu 08:00-16:30 saatleri arası 1 Kahya 16:3000:00 saatleri arası 1 Kahya olmak üzere 2 Kahya, bakım, yem dağıtımı ve sağımdan sorumlu iki vardiya halinde çalışan toplam 13 taşeron iş̧̧i ve 00:00-08:00 saatleri arasında gündüz sağım hazırlığı, bekçilik, acil durumlarda haber ve müdahale için 1 taşeron iş̧̧i sığırcılık şubesinin işçi masraflarını oluşturmaktadır.

Çizelge 4. Sultansuyu tarım işletmesi 2011-2015 yılları arası personel maliyeti (TL) Table 4. Sultansuyu agricultural enterprise personnel cost between 2011 and 2015 (TL)

\begin{tabular}{lccccc}
\hline & 2011 & 2012 & 2013 & 2014 & 2015 \\
\hline Memur & $69.625,6$ & $188.080,2$ & $311.577,4$ & $358.314,0$ & $186.961,3$ \\
Daimi İşçiler & $189.217,8$ & $178.026,2$ & $170.407,2$ & $165.316,3$ & $141.567,2$ \\
Taşeron İşçiler & $189.275,3$ & $216.359,7$ & $240.215,8$ & $212.139,6$ & $222.007,5$ \\
\hline
\end{tabular}

\section{Ekipman Masrafları}

Alet ve ekipman masrafları işletmede o yıl mevcut olarak kullanılan traktör yemleme vagonu, tesviye küreği (sıyırgı), süt sağım makinası vb. gibi hayvancılık faaliyetlerini sürdürmede kullanılan ana ve yardımcı alet ve ekipmanların amortisman değerlerinden sermaye faizi (Anonim, 2017a) düşülerek hayvan başına düşen masraf oranı (BBHB) bulunmuştur. Ayrıca Alet ve Ekipmanların amortisman gideri (EKA) (Anonim, 2017b) hesaplanmıştır.

\section{Yem Giderleri}

Hayvan başına düşen yem giderlerini kuru ot, yonca ve hasıl fiğ balyası, mısır silajı, posa ve kesif yemler oluşturmaktadır. Yemlerin önemli bir miktarı bitkisel üretim faaliyetlerinin sonucu olarak, işletme tarafından karşılanmaktadır. İşletme tarafından 
karşılanan bu yemler üretim maliyetleri belirlenip sığırcılık şubesi masrafları olarak kaydedilmektedir. İşletme tarafından karşılanması mümkün olmayan kesif yem gibi gıda maddeleri de ihale yolu ile serbest piyasa üreticilerinden temin edilmektedir. Hayvanlara verilen yem miktarı giderleri BBHB İşletme tarafından karşılanan BBHB ile dışarıdan temin yolu ile BBHB’nin toplamıyla elde edilmiştir.

\section{İşletmece Karşılanan Yem Masrafları}

Bitkisel üretim faaliyetleri arasında yer alan sap balyası, yonca balyası, hasıl fiğ balyası ve mısır silajı tüketim miktarı Çizelge 5'de verilmiştir. Bu kalemler işletmenin kendi imkânları ve arazilerinin kullanımı ile elde edilen yem çeşitleridir. Toplam maliyetler işletme muhasebe kayıtlarından yararlanılarak BBHB belirlenmiştir.

Çizelge 5. Sultansuyu tarım işletmesinde üretilen yemler ve üretim maliyetleri

Table 5. Feed and production costs produced in Sultansuyu agricultural enterprise

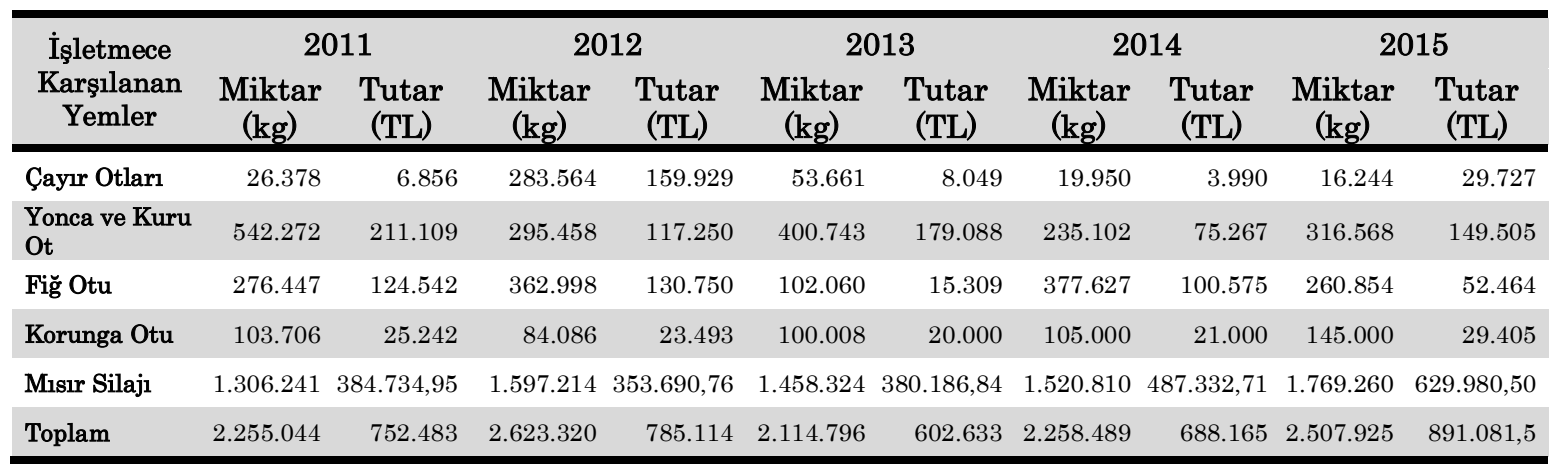

\section{Dışarıdan Temin Yoluyla Oluşan Yem Masrafları}

İşletmenin kendi imkânlarıyla elde edemediği ancak süt verimini arttırmak, dengeli beslenmeye yardımcı olmak ve yeterince iyi rasyon düzeyini elde etmek için ihale veya teklif yolu ile dışarıdan alınan muhtelif posa ve kesif yemlerdir (Çizelge 6). Satın alınan yem miktarları ve fiyatları işletme muhasebe kayıtlarından yararlanarak elde edilmekle birlikte BBHB buradan hesaplanmıştır.

Çizelge 6. Dışarıdan temin ile alınan yemler ve tutarları

Table 6. External feeds takenand their amounts

\begin{tabular}{|c|c|c|c|c|c|c|c|c|c|c|}
\hline \multirow{2}{*}{$\begin{array}{c}\text { Dişarıdan } \\
\text { Karşılanan } \\
\text { Yemler }\end{array}$} & \multicolumn{2}{|c|}{2011} & \multicolumn{2}{|c|}{2012} & \multicolumn{2}{|c|}{2013} & \multicolumn{2}{|c|}{2014} & \multicolumn{2}{|c|}{2015} \\
\hline & $\begin{array}{c}\text { Miktar } \\
(\mathrm{kg})\end{array}$ & $\begin{array}{c}\text { Tutar } \\
\text { (TL) }\end{array}$ & $\begin{array}{c}\text { Miktar } \\
\text { (kg) }\end{array}$ & $\begin{array}{c}\text { Tutar } \\
\text { (TL) }\end{array}$ & $\begin{array}{c}\text { Miktar } \\
\text { (kg) }\end{array}$ & $\begin{array}{c}\text { Tutar } \\
\text { (TL) }\end{array}$ & $\begin{array}{c}\text { Miktar } \\
(\mathrm{kg})\end{array}$ & $\begin{array}{c}\text { Tutar } \\
\text { (TL) }\end{array}$ & $\begin{array}{c}\text { Miktar } \\
\text { (kg) }\end{array}$ & $\begin{array}{c}\text { Tutar } \\
\text { (TL) }\end{array}$ \\
\hline $\begin{array}{l}\text { Diğer Silajlar ve } \\
\text { Posa }\end{array}$ & 809023,0 & 97475,3 & 1159888,0 & 281977,6 & 254566,0 & 6420,1 & 547680,0 & 16429,4 & 161149,8 & 6759,1 \\
\hline Süt Yemi & 536988,0 & 313434,1 & 591562,0 & 494741,5 & 691917,0 & 499200,3 & 685160,0 & 522168,5 & 642390,0 & 475703,3 \\
\hline Besi Yemi & 226756,0 & 126700,7 & 224361,0 & 145302,0 & 233912,0 & 147677,9 & 174292,0 & 116291,0 & 170681,0 & 111667,4 \\
\hline Büyütme Yemi & 38756,0 & 23918,1 & 72020,5 & 48973,9 & 104916,0 & 72683,6 & 94800,0 & 62937,3 & 135179,0 & 94920,0 \\
\hline $\begin{array}{l}\text { Diğer Hazır } \\
\text { Yemler }\end{array}$ & 137087,0 & 75211,1 & 214588,5 & 146578,4 & 117059,0 & 83577,6 & 237289,0 & 152045,0 & 171272,0 & 107937,0 \\
\hline Toplam & 1748610,0 & 636739,2 & 2262420,0 & 1117573,5 & 1402370,0 & 809559,4 & 1739221,0 & 869871,2 & 1280671,8 & 796986,9 \\
\hline
\end{tabular}

\section{Sağllk Giderleri}

Sağlık giderlerini hayvanlar için kullanılan yanıkara, şap, sığır vebası gibi rutin aşılar, hasta bakım ve tedavi ilaçları, dış parazit için karasinek mücadelesi hastalık taşınmasını önleyici dezenfektanlar ve süt sağım makinasında kullanılan kimyasallar oluşturmaktadır. 


\section{İlaç Giderleri}

Sığırlarında insanlarda olduğu gibi belli başlı hastalıklara karşı bağışıklık kazanması için aşı uygulaması yapılmaktadır. İşletmede veteriner sağlık teknisyenleri tarafından düzenli olarak yapılan bu aşılar kulak numarası, yapılan aşı çeşidi ve aşının uygulama şekli olarak işletme aşı takip cetvellerine not alınmakta ve kayıtları tutulmaktadır. Hastalık etmeni taşıyan sinek ve bunun gibi birçok haşereye karşı işletme belirli aralıklarla ilaçlanmakta ve haşere mücadelesi sürdürülmektedir.

Sultansuyu Tarım İşletmesi Müdürlüğü Sığırcılık Tesisleri hastalıklardan ari işletme sertifikasına sahip bir işletmedir. Hastalıklardan ari diğer işletmeler gibi Tarım ve Orman Bakanlığı'nın Resmi gazetede yayınlanan hayvancılık desteklemeleri hakkında uygulama esasları tebliği (Tebliğ no: 2015/17) (Anonim, 2017c) Hastalıklardan ari yönetmenliğine uygun olarak 22. madde doğrultusunda aşılar bağlı bulunan ilçedeki İlçe Tarım Müdürlüğünün denetimi ile düzenli olarak yapılma yoluna gidilmiştir. Bu doğrultuda ilaçlar belirli ölçülerde temin edilerek işletme bünyesinde tutulmak yerine aşı programından hemen önce kullanılacak aşıya göre teklif yolu ile yüklü alımlar yapılmıştır. Muhasebe kayıtlarında mevcut olan bu alımlar işletmedeki hayvan sayısına bölünerek BBHB elde edilmektedir.

\section{Sağım ve Temizlik Kimyasalları Giderleri}

Sağım ünitesi dikkatli kullanılmayıp dezenfektanı yeteri düzeyde yapılmazsa bakteriyel ve viral hastalıklara ve zararlılara karşı ana taşıyıcı ve barındırıcı etken olabilir. Araştırmalar sırasında gözlemlenen ve sağımcılarla yapılan görüşmeler neticesinde her sağımda sağımcı önce ellerini dezenfekte etmekte daha sonra çizmelerini ve sağım önlüğünün dezenfektesini yapmaktadır. Sağım sırası ile genç hayvanlar, yaşlı hayvanlar, tedavi görmüş hayvanlar ve son olarak hasta hayvanlar şeklinde uygulanmaktadır. Sağım bittikten sonra ise meme başları mastitis oluşumunu engellemek için jel bir dezenfektanla kaplanmakta ve son olarak sağım tesisi ile birlikte sütün geçtiği bütün sistemin temizliği ve dezenfektanı sağlanmaktadır.

\section{Diğer Giderler}

Sığırcılık faaliyetlerini doğrudan veya dolaylı yoldan etkileyen toplam maliyeti oluşturan masraf unsurlarının yanında çok daha düşük yüzdelere sahip olan bu giderler akaryakıt, madeni yağlar, yedek parçalar, elektrik ve su ücretleri, inşaat bakım ve onarım masrafları, kırtasiye giderleri, hayvan altlıkları olarak sıralanabilmektedir. Doğrudan etkileyen ve sığırcılık faaliyetlerinde kullanılması gereken üretim dışı atıl durumdaki arpa ve buğday saplarının kullanılmasıyla oluşan hayvan altlıklarını dışarda tutacak olursak bu masraflar herhangi bir üretim şubesinde olduğu gibi hayvancılık şubesini de doğrudan ilgilendirmediğinden öncelikle başka bir hesapta yılsonuna kadar toplanarak yılsonunda şube dağılımlarıyla masraf kaydı olarak geçen giderlerdir.

\section{Gelir Kaynakları}

Herhangi bir süt sığırcılığg işletmesi gibi Sultansuyu Tarım İşletmesi Müdürlüğü Süt Sığırcılığı tesislerinde de birçok kalem halinde bulunan gider kaynaklarına karşın gelir kaynakları süt gelirleri, desteklemeler, gübre gelirleri, kasaplık ve buzağı gelirleri olarak siralanabilmektedir. 


\section{Süt Gelirleri}

Yapılan gözlemler sonucu modern tesislerde el değmeden üretilen sütler sağım sonunda stok tanklarına iletilerek satışa hazır hale getirilmiştir. İşletme şube şefi ile yapılan görüşmelerde süt satışları her yıl öngörülen süt üretimi miktarına göre ihaleye çıkılarak gerekli işletme ve süt işleme belgelerini taşıyan firmalara satışa sunulduğu, tanklarda bekletilen sütler işletmeden kaynaklanan herhangi bir arıza olmadığ müddetçe ihaleyi kazanan firma sorumluluğunda olduğu, ilgili firma her akşam sağımından sonra sütün nakliyesini yapmakla mesul olduğu, yapmadığ takdirde imzalanan sözleşmeye göre üretilen toplam süt miktarının ölçülerek ücretinin firma teslim almış gibi fatura kesileceği bilgilerine ulaşılmıştır. Ayrıca üretilen sütten; yoğurt ve benzeri ürünlere dönüştürülmek ve işletme lojman sakinlerine satılmak üzere istenilen miktarda işletme faydalanma hakkına sahip olduğu da belirtilmiştir. 2015 yılında üretilen süt miktarının bu türde satışı $1,29 \mathrm{TL} \mathrm{kg}^{-1}$ özel sektöre satış fiyatı 1,06 TL kg-1 olarak belirlenmiştir. 2011-2015 yılları arası toplam süt üretim miktarı, süt gelirleri ve dağıtım yerleri Çizelge 7'de verilmiştir.

Çizelge 7. 2015 yılı toplam süt üretim miktarı, süt gelirleri ve dağıtım yerleri

Table 7. 2015 Total milk production, milk revenues and distribution locations

\begin{tabular}{|c|c|c|c|c|c|c|c|c|c|c|}
\hline & \multicolumn{2}{|c|}{2011} & \multicolumn{2}{|c|}{2012} & \multicolumn{2}{|c|}{2013} & \multicolumn{2}{|c|}{2014} & \multicolumn{2}{|c|}{2015} \\
\hline & kg & $\mathrm{TL}$ & kg & TL & kg & TL & kg & TL & kg & TL \\
\hline $\begin{array}{l}\text { Dâhilde } \\
\text { Satılan Süt }\end{array}$ & 61.070 & $39.695,50$ & 58.248 & $46.598,40$ & 64.937 & $57.144,56$ & 54.327 & $54.870,27$ & 55.389 & $58.712,34$ \\
\hline $\begin{array}{l}\text { Harice } \\
\text { Satılan Süt }\end{array}$ & 900.394 & $648.283,68$ & 976.085 & $878.476,50$ & 1.129 .840 & $1.197 .630,40$ & 1.290 .880 & $1.523 .238,40$ & 1.224 .675 & $1.579 .830,75$ \\
\hline $\begin{array}{l}\text { Peynir } \\
\text { İmaline } \\
\text { Verilen Süt }\end{array}$ & 14.540 & $10.468,80$ & & & & & & & 1.700 & $1.802,00$ \\
\hline $\begin{array}{l}\text { Buzağılara } \\
\text { İçirilen Süt }\end{array}$ & 59.240 & 0 & 98.065 & 0 & 106.175 & 0 & 79.607 & 0 & 78.977 & 0 \\
\hline $\begin{array}{l}\text { Toplam } \\
\text { İnek Sütü } \\
\text { İstihsali }\end{array}$ & 1.035 .244 & $698.447,98$ & 1.132 .398 & $925.074,90$ & 1.300 .952 & $1.254 .774,96$ & 1.424 .814 & $1.578 .108,67$ & 1.360 .741 & $1.640 .345,09$ \\
\hline
\end{tabular}

\section{Damızlık ve Reforme Gelirleri}

Damızlık ve reforme gelirleri, bir süt sığırcılığı tesisinde önem sıralaması yapacak olursak süt gelirlerinden sonra ikinci sırada yer alacaktır. İşletme tesis kapasitesi fazlalarının diğer işletmelere gönderilmesi, bakanlığın belirli dönemlerde yaptı̆̆ çalışmalar sonucu vatandaşa hibe edilip bakanlığa fatura edilmesi, işletme dışında vatandaşa ve özel firmalara satılması sonucu elde edilen gelirlerdir.

Doğan erkek yavrular nadir durumlarda (Boğa istasyonunca sperma sağımı için kullanılmadıkça) damızlık olarak satışa sunulmuştur. Damızlık fiyatları hastalıklardan ari işletme olması ve üstün vasıflı hayvanlar yetiştirilmesi sebebiyle bütün TİGEM'de Türkiye geneli hayvan piyasasının üstündedir. İşletmede doğan buzağıların sütten kesildikten sonraki dönemlerde veya Genel Müdürlükçe ve Bakanlıkça belirlenen politikalar gereği dana, düve veya genç boğa olarak satışı gerçekleşmiştir.

Sağım kayıtlarının tutulması ve her gün incelenmesi sonucu süt verimi ekonomik eşiğin altına düşmüş inekler ile beraber birkaç kez tohumlama denenmesine rağmen gebeliği gerçekleşmemiş yapılan incelemeler sonucu kısır olduğu kesinleşmiş düveler reforme olarak ayrıldıktan sonra açık arttırma yolu ile satışa sunulmuştur. 


\section{Teşvikler ve Diğer Gelirler}

Başbakanlık Mevzuatı Geliştirme ve Yayın Genel Müdürlüğünce yayınlanan 28612 nolu Resmi Gazetede (Anonim, 2017d) 2013 yılında yapılacak tarımsal desteklemelere ilişkin Bakanlar Kurulu kararı çerçevesinde; hastalıklardan ari sağlık sertifikasını elinde bulunduran ve büyükbaş hayvan sayısı 500'ü geçmeyen işletmelere yaşı altı ayı

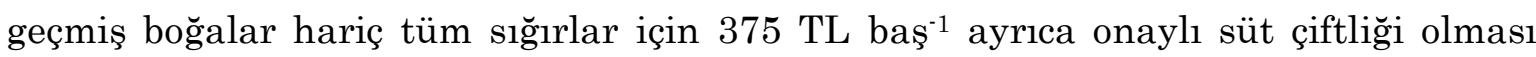
halinde ise ilave $50 \mathrm{TL}_{\text {baş }}^{-1}$ destekleme ödemesi yapılacağı bildirilmiştir. Büyükbaş hayvan sayısı 501 ve üzerinde olan işletmeler için bu ödemelerin \%50'sine karşllık gelen tutarınca yapılacağı bildirilmiştir. Aynı kararda suni tohumlamadan ve etçil ırklardan doğan buzağılar için $75 \mathrm{TL}_{\text {baş }}^{-1}$ döl kontrolü projesi kapsamında suni tohumlamadan doğan buzağıya ise ek olarak 35 TL baş ${ }^{-1}$ ödeme yapılacağı ayrıca şap aşısı için hayvan başına 0.75 TL ödeme yapılacağı bildirilmiştir. 2015 yılında ilgili maddeler ve bu rakamlar değişmeden desteklemeler aynı şekilde uygulanmaya devam edilmiştir. Sultansuyu Tarım İşletmesi Müdürlüğü ilgili maddelerin tümünü karşlamasına rağmen devlete bağlı bir KİT kuruluşu olması sebebiyle desteklemelerin hiçbirinden yararlanamamıştır. Araştırmanın bu özelliği diğer araştırmalara karşı ayırt edici bir unsurdur.

Hastalık ya da sakatlanma gibi hayatını idame ettirmesi güç duruma düşmüş bunun sonucu olarak mecburi kesimi yapılmış hayvanlar insan sağlığını etkilemeyecek onayı alarak ücreti mukabilinde iaşe ve lojman personeline dağıtılmıştır. Elde edilen miktar hayvancılık muhasebe kayıtları hanesine gelir olarak kayda geçmiştir.

Bir büyükbaş hayvan günde ağırlığının \%5-6’sı kadar yaş gübre üretmektedir. Diğer bir yaklaşımla bir büyükbaştan yıllık ortalama 3.6 t gübre elde edilmiştir (Berkes ve Kışlalıŏlu, 1993). Sultansuyu Tarım İşletmesi hayvanlardan elde edilen gübreyi tarlalara organik gübre olarak taşımaktadır. Taşıma esnasında yapılan gözlemlere göre işletmeden tarlaya giden her taşıt için ilk beş seferde taşıt cinsinin ve yük kapasitesinin kayıt altına alınarak taşıt cinsleri için belirlenen ortalama miktarın toplam sefer sayısıyla çarpılması sonucu tarlalara atılan gübre miktarı kg olarak hesaplanmıştır. $\mathrm{Bu}$ yöntem ara ara tekrarlanarak en doğru sonuç elde edilmeye çalışılmıştır. 2015 yılı toplam üretilen gübre miktarı gübreliklere çekilmiş ve üzerinden 1 sene geçtikten sonra tarlaya taşınmıştır. Tarlaya taşınan gübre miktarı 2016 yılı için muhasebe kayıtlarına $2565000 \mathrm{~kg}$ olarak geçmiştir. Üretilip tarlaya taşınan gübreler doğru analiz için 0.10 Krş olarak tarla şubesine masraf kaydı hayvancılık şubesine ise girdi olarak kaydı alınmıştır.

Sultansuyu Tarım İşletmesi hayvancılık şubesinde yapılan süt sığırcılığı faaliyetlerinin ne kadar verimli olduğunun belirlenmesi ve ekonomik analizinin ortaya konulmasına yönelik bulgular Sultansuyu TíM'in çalışanlarıyla yapılan gözlemler ve doğrudan muhasebe kayıtlarından alınan verilerle elde edilmiştir. Bu veriler Çizelge 8'de aşağıdaki gibi gösterilmiştir. 
Çizelge 8. 2011-2015 yılları arası gelir ve gider yüzdeleri

Table 8. Income and expense percentages between 2011 and 2015

\begin{tabular}{|c|c|c|c|c|c|c|}
\hline & $\begin{array}{l}\text { GELIR VE GIDER } \\
\text { (TL) }\end{array}$ & $\begin{array}{c}2011 \\
\text { ORAN \% }\end{array}$ & $\begin{array}{c}2012 \\
\text { ORAN \% }\end{array}$ & $\begin{array}{c}2013 \\
\text { ORAN \% }\end{array}$ & $\begin{array}{c}2014 \\
\text { ORAN \% }\end{array}$ & $\begin{array}{c}2015 \\
\text { ORAN \% }\end{array}$ \\
\hline \multirow{7}{*}{ 罢 } & Süt Geliri & 37,6 & 42,0 & 38,8 & 48,8 & 41,6 \\
\hline & Damızlık Geliri & 14,2 & 0,7 & 18,7 & 0,5 & 5,1 \\
\hline & Reforme ve Kasaplık Geliri & 4,2 & 17,0 & 5,8 & 8,4 & 9,6 \\
\hline & Buzağ ${ }_{1}$ Geliri & 15,1 & 14,7 & 15,5 & 9,5 & 8,7 \\
\hline & Çağ Farkı Geliri & 20,4 & 15,6 & 10,6 & 25,4 & 28,1 \\
\hline & Sığır Derisi Geliri & 0,1 & 0,1 & 0,2 & 0,1 & 0,1 \\
\hline & Sığır Gübresi Geliri & 8,4 & 9,8 & 10,4 & 7,4 & 6,8 \\
\hline \multirow{6}{*}{ 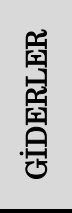 } & Yem Masrafları & 62,1 & 60,8 & 55,3 & 59,3 & 60,5 \\
\hline & Teknik Eleman Gideri & 2,8 & 6,9 & 8,1 & 6,3 & 5,7 \\
\hline & İşçi Gideri Gideri & 15,4 & 12,5 & 14,4 & 13,6 & 11,0 \\
\hline & Amortisman Gideri & 12,4 & 9,6 & 10,6 & 11,0 & 12,2 \\
\hline & Diğer Giderler & 3,5 & 6,3 & 6,6 & 6,4 & 7,9 \\
\hline & İlaç ve Kimyasal Giderleri & 3,8 & 3,9 & 5,0 & 3,4 & 2,7 \\
\hline
\end{tabular}

İşletmede maliyeti oluşturan masraf unsurları kalem kalem incelendiğinde toplam maliyetin \%59.6'sını ilk sırada yer alan yem masrafları bunu \%19.34 ile teknik eleman ve işçi masrafları, \%11.16 ile amortisman giderlerinin \%6.14 ile diğer giderleri ve \%3.76 ile ilaç giderleri takip etmiştir.

İçöz (2004) yapmış olduğu çalışmada, maliyeti oluşturan masraf unsurlarını; \%58.14 ile yem, \%22.31 ile işçilik, \%5.96 ile amortismanlar, \%3.74 ile veteriner-sağlık, \%3.01 ile faiz giderleri, \%1.29 ile bakım־onarım giderleri ve \%5.55 ile de diğer giderler olarak hesaplandığını bildirmişlerdir. Gelir kalemlerini ise \%59.07 ile süt satışından elde edilen gelir, \%12.45 ile buzağı geliri, \%27.12 ile hayvan envanter kıymet artışı ve \%1,36 ile de gübre gelirleri şeklinde gerçekleştiğini bildirmişlerdir. Yapmış olduğumuz bu çalışma mercek altına alınacak olunursa yem ve işçilik giderleriyle İçöz'ün yapmış olduğu çalışmayla yakın olmakla birlikte amortisman ve veteriner sağlık giderleriyle birbirinden ayrılmaktadır. Gelir kalemlerine bakıldığında ise iki çalışma birbiriyle tamamen farklılık göstermektedir.

Yıldırım ve Şahin (2003), çalışmalarında Van ili Merkez ilçede süt sığırcılığı yapan işletmelerin ekonomik analizi başlığı altında yaptığı araştırmada, brüt üretim gelirlerinin kültür ırkı ve kültür melezi süt sığırcılığı yapan işletmelerde \%46.92'si süt ve süt ürünlerinden oluştuğunu gözlemlemiş ve çalışmamızla benzer oranlarda gelirin sütten yapıldığını ortaya koymuştur.

Tandoğan (2006) tarafından yapılan çalışmada, Afyonkarahisar ili merkez ve ilçelerinde damızlık sığır yetiştiricileri birliği 'ne bağlı faaliyet gösteren 78 adet süt sığırcılığ̣ işletmesinin 1 yıllık üretim dönemi verileri incelenmiştir. İşletmelerin masraf kalemlerinin \%47.82'sinin yem, \%26.97'sinin işçilik, \%4.25'inin sağlık, \%2.59'unun genel idare, \%3.25'inin bakım-onarım, \%7.84'ünün amortisman ve \%7.28'inin de diğer masraflardan oluştuğunu ve işletmelerde elde edilen gelirin oransal dağılımının da \%52 ile süt gelirleri, \%6,49 ile buzağı gelirleri ve \%40,83 ile de envanter kıymet artışından oluştuğunu bildirmiştir.

Çelik (2014) tarafından yapılan çalışmada, girdi unsurlarının $\% 42.95$ ile besi materyali, \%33.09 ile yem, \%9.63 ile işçilik, \%1.73 ile veteriner-sağlık giderleri, \%1.64 ile bakım-onarım, \%1.56 ile amortisman ve \%0.84 ile de diğer giderlerin oluşturduğu tespit edilmiştir. Araştırmacı $1 \mathrm{~kg}$ canlı ağırlık artışı için $7.77 \mathrm{~kg}$ kesif yem tüketildiğini, $1 \mathrm{~kg}$ canlı ağırlık maliyetinin küçük, orta ve büyük ölçekli işletmelerde sırasıyla 9.70 TL, 8.82 TL ve 7.76 TL olarak hesaplandığını ve büyük ve orta ölçekli 
işletmelerde sırasıyla 606.19 TL baş ${ }^{-1}$ ve 132.64 TL baş ${ }^{-1}$ kâr elde edilirken, küçük ölçekli işletmelerin 492.35 TLbaş $^{-1}$ zarar ettiğini rapor etmiştir.

Alyeşil ve Gözener (2018) yaptıkları çalışmada, Kazova Vasfi Diren Tarım İşletmesi süt sığırcılı̆̆ı bölümünün üretim masrafları ve ürün maliyetlerinin belirlenmesi amacıyla yaptıkları çalışmada, 2016 yılı gerçek üretim şartlarında süt sığırcılığı faaliyetine ilişkin muhasebe ve işletme kayıtları kullanarak, işletmenin masraf unsurları arasında toplam masrafların \%52.09'unu yem masrafları, \%17.17'sini işçilik masrafları, \%12.63'ünü amortismanlar, \%2.11'ini ilaç masrafları ve \%16.00'sını ise diğer masrafların oluşturduğunu tespit etmişlerdir. Gelir kaynaklarının \%71.27’lık kısmını süt gelirleri, \%7.62'sini erkek buzağı gelirleri, \%16.53’ünü sigorta hasar gelirleri ve \%4.58'ini desteklemelerin oluşturduğunuve araştırma sonucunda Gelir/ Gider oranı \%13.16, faaliyet karı ise \%5.28 olarak hesaplandığını bildirmişlerdir.

\section{SONUÇ}

Bulgular ışığında araştırma sonuçlarına göre, aşağıdaki öneriler yapılmıştır.

Araştırmada toplam giderlerin \%19.34'ünü işçilik giderlerinin oluşturduğu bunların ise kendi içerisinde \%8.12'sini taşeron iş̧̧ileri \%5.96'sını memur ücretleri ve \%5.26'sını ise kadrolu işçilerin oluşturduğu yapılan hesaplar sonucu tespit edilmiştir. Yem giderleri işletme giderleri arasında toplam giderlerin \%59.6'sının yem giderleri olduğu saptanmıştır. Veteriner Hekim giderleri işçilik giderleri arasında incelenmiştir. $\mathrm{Bu}$ nedenle sağlık giderleri sadece ilaç ve dezenfektan masrafları başlıkları halinde toplam masrafların \%3.76’sını oluşturmaktadır. İşletme ilaçları teklif yolu ile alındığından yaplacak teklif veya ihalelerde kullanılacak ilacın etken madde oranının belirtilmesi kaliteli ilaç eldesi için dikkat edilmesi gereken hususlardandır. Hastalıklardan ari bir işletme olan Sultansuyu TİM'de işletme sertifikasının devamını sağlamak için çalışan işçilere hastalıklar, haşereler ve sağım makinası dezenfeksiyonu hakkında belirli aralıklarla seminerler verilip işçilerin bu konu hakkında bilgi sahibi olmaları amaçlanmalıdır.

Muhasebe kayıtlarında amortisman gideri olarak her sene alet ekipman ve hayvan varlıkları üzerinden \%25 amortisman düştüğü gözlenmiştir. Canlı varlıkların ve ekipmanların amortismanları ayrı ayrı incelenmeli, amortismanı düşülecek her varlığın ekonomik ömrü dikkate alınarak düşülecek amortisman bedeli belirlenmelidir. $\mathrm{Bu}$ şekilde düşülen amortisman bedelleri ile işletme karlılık analizinde daha doğru sonuçlar elde edilmektedir. İşletmedeki hayvan sayısının düşük olması çalışan memur ve kadrolu iş̧̧ilerin BBHB başına düşen maliyeti arttırmaktadır. Hayvan sayısının arttırılması memur ve kadrolu iş̧̧ilerin BBHB başına düşen maliyeti azaltacağı gibi BBHB başına düşen amortisman giderlerinde de önemli ölçüde azalma görülecektir.

Herhangi bir süt sığırcılığı işletmesindeki beklentilerde olduğu gibi yapılan araştırmada da gelir kaynaklarının \%41.76'lık kısmını oluşturan süt gelirleri ilk sırada yerini almaktadır. Bunu \%29.52 ile damızlık ve reforme gelirleri, \%20.02 ile çă̆ farkı gelirleri, \%8.56 ile gübre gelirleri ve \%0.1 ile sığır derisi gelirleri izlemektedir. Damızlık ve reforme gelirlerinin kendi içerisinde toplam gelir oranlarındaki payı \%8.99 reforme ve kasaplık, \%12.70 buzağı ve \%7.83 damızlık olarak ayırmak mümkündür. Reforme gelirlerinin ve çağ değişim gelirlerinin toplam gelirler içerisindeki getirisinin yüksek oranda olması çağ değişiminin belirli bir yıl içerisine sıkıştığının göstergesidir. Çağ değişimlerini fazla büyük sayılmayacak 200 başlı işletmelerde belirli bir yıl içerisine 
sıkıştırmak ana kadroda eksiklikler meydana getirebileceği gibi ekonomik olarak BBHB başına düşen süt verimini düşürecektir. Tutulan kayıt defterlerinde ineklerin yaşı ve süt verimi dikkate alınarak çağ değişimleri daha küçük oranlarda uzun dönemler halinde yapılmalıdır.

\section{ÇIKAR ÇATIŞMASI}

Yazarlar arasında herhangi bir çıkar çatışması bulunmamaktadır.

\section{YAZAR KATKISI}

$\mathrm{Bu}$ makale, Yüksek lisans tezinden hazırlanmıştır.

Veysel Kaya Yığmatepe: çalışmanın giriş, materyal ve yöntem, sonuç bölümlerinin hazirlanmasinda,

Mehmet Metin Özgüven: Makalenin gözden geçirilmesinde katkıda bulunmuştur.

\section{KAYNAKLAR}

Alyeşil H ve Gözener B (2018). Kazova Vasfi Diren tarım işletmesi süt sığırcılığı faaliyetinin ekonomik analizi. Gaziosmanpaşa Bilimsel Araştırma Dergisi, 7 (1): 87-100.

Anonim (2000). Uzun vadeli strateji ve sekizinci beş yıllık kalkınma planı 2001-2005. http://www3.kalkinma.gov.tr/DocObjects/View/13743/plan8.pdf.

Anonim (2013a). Tarım İşletmeleri Genel Müdürlüğü hayvancılık sektör raporu. Ankara.

Anonim (2013b). Dünya ve Türkiye'de süt sektör istatistikleri. Ulusal Süt Konseyi, Ankara.

Anonim (2015a). Kırmızı et stratejisi. Gıda Tarım ve Hayvancılık Bakanlığı Hayvancılık Genel Müdürlüğü. Ankara.

Anonim (2015b). Hayvancılık raporu. Gıda Tarım ve Hayvancılık Bakanlığı GAP Uluslararası Tarımsal Araştırma ve Eğitim Merkezi. Diyarbakır.

Anonim (2015c). Hayvancılık Sektör Raporu. TİGEM.

Anonim (2017a). http://www.gib.gov.tr/sites/default/files/fileadmin/user_upload/Yararli_Bilgiler/ amortisman_oranlari.pdf. (20.05.2017).

Anonim (2017b). http://www.tcmb.gov.tr/wps/wcm/connect/6121b7aa-7946-4353-b0f2-9cbab7e289b2 /Turk+Lirasi.html?MOD=AJPERES\&CVID=. (20.05.2017).

Anonim (2017c). http://www.resmigazete.gov.tr/eskiler/2015/05/20150512-2.htm. (24.05.2017).

Anonim (2017d). http://www.resmigazete.gov.tr/eskiler/2013/04/20130408-5.htm (28.05.2017).

Aras A (1988). Tarım muhasebesi, Ege Üniversitesi, Ziraat Fakültesi Yayınları, No:486, E.Ü. Basımevi, Bornova-İzmir

Berkes F ve Kışlalıŏlu MB (1993). Çevre ve Ekoloji, 4.Basım, Remzi Kitabevi, İstanbul.

Çelik C (2014). Kırşsehir ili merkez ilçede sı̆̆gr besiciliği yapan işletmelerin ekonomik analizi. Yüksek Lisans Tezi, Erciyes Üniversitesi Sağlık Bilimleri Enstitüsü. Hayvan Sağlığı Ekonomisi ve İşletmeciliği Anabilim Dalı, s. 78, Ankara.

Çiçek A ve Erkan O (1996). Tarım ekonomisinde araştırma ve örnekleme metotları. Gaziosmanpaşa Üniversitesi Ziraat Fakültesi Yayınları No: 12. Ders Kitapları Serisi No: 6. Tokat.

Erkuş A, Bülbül M, Kıral T, Açıl AF ve Demirci R (1995). Tarım ekonomisi, Ankara Üniversitesi Ziraat Fakültesi Ë̆̈itim, Araştırma ve Geliștirme Vakfı Yayınları, Yayın No:5, Ankara

Güneş T ve Arıkan R (1985). Tarım ekonomisi istatistiği. Ankara Üniversitesi, Ziraat Fakültesi Yayınları: 1049, Ders Kitabı No: 305, Ankara.

Hacıhasanoğlu T (2015). Hayvancılık sektöründe maliyet, hacim, kar analizi. Gazi Kitabevi. Ankara.

İçöz Y (2004). Bursa ili süt sığırcılığı işletmelerinin karlılık ve verimlilik analizi. Tarım ve Köyişleri Bakanlığı Tarımsal Ekonomi Araştırma Enstitüsü, Tarım ve Köyişleri Bakanlı̆̆ Tarımsal Ekonomi Araştırma Enstitüsü Yayın No: 116, Ankara.

MEB (2012). Görüşme Teknikleri. Millî Eğitim Bakanlığı, MEGEP Halkla İlişkiler Ve Organizasyon Hizmetleri Modülü. Ankara.

Özgüven MM (2017). Hassas hayvansal üretim. Tarım Türk Dergisi. Kasım-Aralık 2017. Sayı: 27. 
Şeker İ, Tasalı H ve Güler H (2012). Muş ilinde sığır yetiştiriciliği yapılan işletmelerin yapısal analizi. Firat Üniversitesi Sağllk Bilimleri Veteriner Dergisi, 26 (1): 09-16.

Tandoğan M (2006). Afyonkarahisar süt sığırcılık işletmelerinde karlılık analizi ile işletmelerde karşılaşılan üretim ve pazarlama sorunları. Yüksek Lisans Tezi, Afyon Kocatepe Üniversitesi, Sağlık Bilimleri Enstitüsü, Hayvan İşletme Ekonomisi Anabilim Dalı, s.74, Afyon.

Ünal RN ve Besler T (2008). Beslenmede sütün önemi. Hacettepe Üniversitesi Sağlık Bilimleri Fakültesi Beslenme ve Diyetetik Bölümü. Sağlık Bakanlı̆̆ Yayın No: 727. Ankara.

Yıldırım İ ve Şahin A (2003). Van ili merkez ilçede süt sığırcılı̆̆ı yapan işletmelerin ekonomik analizi, Yüzüncü Yıl Üniversitesi, Ziraat Fak. Van Ticaret Borsası Yayınları No: 1, s. 52, Van. 